\title{
Unexpected Formation and Molecular Structure of a Stable Dinuclear Rhodlum Compound with a Single Chloro Bridge, (CO) ${ }_{2} \mathrm{ClRh}(\mu-\mathrm{Cl}) \mathrm{Rh}(\mathrm{CO})\left\{\mathrm{C}_{6} \mathrm{H}_{5} \mathrm{P}\left[\mathrm{OC}\left(\mathrm{CH}_{3}\right)_{2} \mathrm{CH}_{2}\right]_{2} \mathrm{NH}\right\}$
}

\author{
Joachim Wachter, "1a François Jeanneaux, ${ }^{10}$ Guy Le Borgne, ${ }^{10}$ and Jean G. Riess* ${ }^{\text {1b }}$ \\ Institut für Anorganische Chemie, Universität Regensburg, D-8400 Regensburg, West Germany, Laboratoire de \\ Chimie Minërale Molêculaire, Equipe de Recherche Associêe au CNRS No. 473, Université de Nice, Parc \\ Valrose, 06034 Nice, France, and Laboratoire de Cristallochimie, Universitê de Rennes, 35042 Rennes, France \\ Received February 17, 1984
}

\begin{abstract}
The reaction of $\left[\mathrm{Rh}(\mathrm{CO})_{2} \mathrm{Cl}\right]_{2}$ with the bicyclic aminophosphorane $\mathrm{H}\left(\mathrm{C}_{6} \mathrm{H}_{5}\right) \mathrm{P}\left[\mathrm{OC}\left(\mathrm{CH}_{3}\right)_{2} \mathrm{CH}_{2}\right]_{2} \mathrm{~N}$ has been reinvestigated with respect to its stoichiometry. It led, for a $2: 1 \mathrm{Rh} /$ ligand ratio, to the stable hitherto unknown dirhodium arrangement having only a single chlorine bridge, $(\mathrm{CO})_{2} \mathrm{ClRh}(\mu-\mathrm{Cl}) \mathrm{Rh}(\mathrm{CO}) \mathrm{L}$, where $\mathrm{L}$ is the phosphorus- and nitrogen-bound ligand $\mathrm{PhP}\left[\mathrm{OC}\left(\mathrm{CH}_{3}\right)_{2} \mathrm{CH}_{2}\right]_{2} \mathrm{NH}$, instead of the mononuclear adduct $\mathrm{Rh}(\mathrm{CO}) \mathrm{ClL}$ obtained for a 1:1 $\mathrm{Rh} /$ ligand ratio. This novel compound displays two differently substituted Rh atoms whose actual charges are different and is open to nucleophilic attack. Its structure was established by an X-ray structural determination, which showed that two square planes, each centered around one $\mathrm{Rh}$ atom, are linked together directly by one chlorine atom only and indirectly by a $\mathrm{Cl}$... $\mathrm{H}-\mathrm{N}$ hydrogen bond, so as to form a dihedral angle of $86.2^{\circ}$. The implications of the new complex with respect to the mechanism of the reaction of $\left[\mathrm{Rh}(\mathrm{CO})_{2} \mathrm{Cl}\right]_{2}$ with ligands are discussed.
\end{abstract}

The bicyclic aminophosphoranes of type 1 have been shown to react with rhodium(I) derivatives with formation of chelated adducts of type 3 , containing a bidentate phosphorus/nitrogen ligand ${ }^{2}$ (eq 1). High yields of 3 were isolated when the ligand/metal ratio was $1: 1$. When 2 molar equiv of 1 were allowed to react with $\left[\mathrm{Rh}\left(\mathrm{C}_{2} \mathrm{H}_{4}\right)_{2} \mathrm{Cl}\right]_{2}$, the doubly chelated adduct 4 was obtained; the substitution of a second $\mathrm{CO}$ in $\left[\mathrm{Rh}(\mathrm{CO})_{2} \mathrm{Cl}\right]_{2}$ was not observed under the same conditions. The structures of several complexes of types 3 and 4 have been carefully examined by X-ray crystallography. ${ }^{2,3}$ All these reactions involve both the splitting of the chloride bridge and the displacement of $\mathrm{CO}$. An insight into the reaction pathway is provided by the reaction of tertiary phosphanes with $\left[\mathrm{Rh}(\mathrm{CO})_{2} \mathrm{Cl}\right]_{2}$ : with an excess of ligand, mononuclear complexes ${ }^{4,5}$ are also obtained, but with a 1:1 phosphane/Rh molar ratio the stable bis( $\mu$-chloro) complexes $\left[\mathrm{RhCl}(\mathrm{CO}) \mathrm{PR}_{3}\right]_{2}$ were isolated. In no case was a binuclear complex having only one chlorine bridge observed. More generally, the authors are not aware of any example of a singly bridged dirhodium compound such as those reported in this paper.

\section{Experimental Section}

General Data. All procedures were carried out under dry deoxygenated nitrogen with solvents freshly distilled under nitrogen from appropriate drying agents. The bicyclic aminophosphorane $\mathrm{H}\left(\mathrm{C}_{6} \mathrm{H}_{5}\right) \mathrm{P}\left[\mathrm{OC}\left(\mathrm{CH}_{3}\right)_{2} \mathrm{CH}_{2}\right]_{2} \mathrm{~N}$ (abbreviated $\mathrm{Me}_{4}$ phoran), 1a, was prepared according to a published procedure. ${ }^{6}$ Elemental analyses were performed by the Mikroanalytisches Laboratorium, Universität Regensburg, and by the Service Central d'Analyses du CNRS. Infrared spectra were obtained with a Beckman 4240 spectrophotometer. NMR spectra were recorded at 90 and $36.45 \mathrm{MHz}$ for ${ }^{1} \mathrm{H}$ and ${ }^{31} \mathrm{P}$, respectively, on a Bruker

(1) (a) Universität Regensburg. (b) Universitê de Nice. (c) Universitê de Rennes.

(2) Bondoux, D.; Tkatchenko, I.; Houalla, D.; Wolf, R.; Pradat, C.; Riess, J. G.; Mentzen, B. F. J. Chem. Soc., Chem. Commun. 1978, 1022 Pradat, C.; Riess, J. G.; Bondoux, D.; Mentzen, B. F.; Tkatchenko, I.; Houalla, D. J. Am. Chem. Soc. 1979, 101, 2234.

(3) Bondoux, D.; Mentzen, B. F.; Tkatchenko, I. Inorg. Chem. 1981, 20,839 .

(4) For a review see: Uguagliati, P.; Deganello, G.; Belluco, U. Inorg. Chim. Acta 1974, 9, 203.

(5) Pribula, A. J.; Drago, R. S. J. Am. Chem. Soc. 1976, 98, 2784.

(6) Bonningue, C. Thesis Universitê de Toulouse, 1980.
WH-90 DS spectrometer, broad-band decoupled, for ${ }^{31} \mathrm{P}$.

(CO) ${ }_{2} \mathrm{ClRh}(\mu-\mathrm{Cl}) \mathrm{Rh}(\mathrm{CO})\left(\mathrm{Me}_{4}\right.$-phoran) (5a). A mixture of $\left[\mathrm{Rh}(\mathrm{CO})_{2} \mathrm{Cl}_{2}(190 \mathrm{mg}, 0.5 \mathrm{mmol})\right.$ with $\mathrm{Me}_{4}$-phoran (134 mg, 0.5 mmol) and $10 \mathrm{~mL}$ of toluene was stirred in the absence of light at room temperature for $15 \mathrm{~min}$. After evaporation of the solvent the oily residue was washed with $15 \mathrm{~mL}$ of pentane, to give a yellow powder. The IR spectra show that all the starting materials had been consumed and that $\mathbf{5 a}$ had been formed almost quantitatively; no mononuclear 3a was detected. The crude product was dissolved in $20 \mathrm{~mL}$ of toluene, filtered over $1 \mathrm{~cm}$ of $\mathrm{SiO}_{2}$, and then recrystallized from a mixture of $10 \mathrm{~mL}$ of toluene and $5 \mathrm{~mL}$ of pentane to give $126 \mathrm{mg}$ (40\%) of yellow-brown crystals of 5a: IR $(\mathrm{KBr}) \nu_{\mathrm{NH}} 3164(\mathrm{~m}), \nu_{\mathrm{CO}} 2074,2008,1998(\mathrm{vs}) ;{ }^{1} \mathrm{H} \mathrm{NMR} \delta_{\mathrm{CH}_{3}} 0.87$ (s), 0.89 (s), 2.05 (s), $\delta_{\mathrm{CH}_{2}} 2.06$ (d), 2.09 (d), 2.97 (d), 3.06 (d, $J_{\mathrm{CH}-\mathrm{H}}$ $=14 \mathrm{~Hz}), \delta_{\mathrm{NH}} 6.19(\mathrm{~m}), \delta_{\mathrm{C}_{6} \mathrm{H}_{5}} 7.08(\mathrm{~m}), 7.62(\mathrm{~m}),\left(\mathrm{C}_{6} \mathrm{D}_{6}\right) ;{ }^{31} \mathrm{P} \mathrm{NMR}$ $144.9\left(\mathrm{~d}, J_{\mathrm{P}-\mathrm{Rh}}=180 \mathrm{~Hz}\right)\left(\mathrm{Me}_{2} \mathrm{SO}-d_{6}\right) ; \mathrm{mp} 165^{\circ} \mathrm{C}$ dec. Anal. Calcd for $\mathrm{C}_{17} \mathrm{H}_{22} \mathrm{Cl}_{2} \mathrm{NO}_{5} \mathrm{PRh}_{2}$ : C, 32.51; $\mathrm{H}, 3.53 ; \mathrm{N}, 2.23 ; \mathrm{Cl}, 11.29 ; \mathrm{mol}$ wt 628.0 . Found: C, $32.81 ; \mathrm{H}, 3.52 ; \mathrm{N}, 2.18 ; \mathrm{Cl}, 10.98$; mol wt 628 (mass spectroscopy, field desorption).

Reaction of $(\mathrm{CO})_{2} \mathrm{ClRh}(\mu-\mathrm{Cl}) \mathrm{Rh}(\mathrm{CO})\left(\mathrm{Me}_{4}\right.$-phoran) (5a) with $\mathrm{Me}_{4}$-phoran (1a). A solution of $5 \mathrm{a}(314 \mathrm{mg}, 0.5 \mathrm{mmol})$ in $10 \mathrm{~mL}$ of toluene was added to a solution of $1 \mathrm{a}(134 \mathrm{mg}, 0.5 \mathrm{mmol})$ in $5 \mathrm{~mL}$ of toluene in the absence of light. After $15 \mathrm{~min}$, the solution was chromatographed on $\mathrm{SiO}_{2}(8 \times 2 \mathrm{~cm}$ column $)$. A pale yellow band was eluted with a mixture of toluene/acetone $(10: 1)$. Recrystallization from a mixture of toluene/pentane (5:2) yielded $85 \mathrm{mg}(40 \%)$ of yellow crystals of $3 \mathrm{a}$. This product is identical in its spectroscopic properties with those measured on the product directly synthesized from $1 \mathrm{a}$ and 2.

Direct Synthesis of (CO)ClRh(Me $\mathrm{Me}_{4}$-phoran) (3a). A solution of $1 \mathrm{a}(267 \mathrm{mg}, 1.0 \mathrm{mmol})$ in $10 \mathrm{~mL}$ of toluene was added at room temperature to a solution of $2(194 \mathrm{mg}, 0.5 \mathrm{mmol})$ in 10 $\mathrm{mL}$ of toluene. Immediately a bright yellow solid precipitated; this was filtered and washed twice with small portions of pentane to yield $403 \mathrm{mg}(93 \%)$ of the crude product. Recrystallization from toluene resulted in yellow crystals of $3 \mathbf{a}$ : $\mathbf{I R}(\mathrm{KBr}) \nu_{\mathrm{NH}} 3200$ $(\mathrm{m}), \nu_{\mathrm{CO}} 2000(\mathrm{vs}) ;{ }^{1} \mathrm{H}$ NMR $\delta_{\mathrm{CH}_{3}} 1.03(\mathrm{~s}), 2.16(\mathrm{~s}), \delta_{\mathrm{CH}_{2}} 2.52(\mathrm{~d})$, $2.60(\mathrm{~d}), 3.52(\mathrm{~d}), 3.56\left(\mathrm{~d}, J_{\mathrm{CH}-\mathrm{H}}=14 \mathrm{~Hz}\right), \delta_{\mathrm{NH}} 6.07(\mathrm{~m}), \delta_{\mathrm{C}_{\mathrm{e}} \mathrm{H}_{5}} 7.05$ $(\mathrm{m}), 7.76(\mathrm{~m})\left(\mathrm{C}_{6} \mathrm{D}_{6}\right)$; ${ }^{31} \mathrm{P}$ NMR $144.9\left(\mathrm{~d}, J_{\mathrm{P}-\mathrm{Rh}}=179 \mathrm{~Hz}\right)$ $\left(\mathrm{Me}_{2} \mathrm{SO}-d_{6}\right) ; \mathrm{mp} 195^{\circ} \mathrm{C}$ dec. Anal. Calcd for $\mathrm{C}_{15} \mathrm{H}_{22} \mathrm{ClNO}_{3} \mathrm{PRh}$ : C, $41.54 ; \mathrm{H}, 5.31 ; \mathrm{N}, 3.23 ; \mathrm{Cl}, 8.18$; mol wt 433.7 . Found: $\mathrm{C}, 41.35$; $\mathrm{H}, 4.93 ; \mathrm{N}, 3.40 ; \mathrm{Cl}, 7.90$; mol wt 433 (70-eV mass spectroscopy).

Solution of the Structure of 5a. Weissenberg and precession photographs showed the crystal to be triclinic with the cell dimensions $a=10.18$ (1) $\AA, b=12.77$ (2) $\AA, c=10.04$ (1) $\AA, \alpha=$ $104.71(7)^{\circ}, \beta=100.31(7)^{\circ}, \gamma=70.55(9)^{\circ}, V=1184.2 \AA^{3}$. The space group is $P \overline{1}$, with $Z=2, d_{\text {calcd }}=1.76 \mathrm{~g} \cdot \mathrm{cm}^{-3}$. The unit cell parameters were refined by using the $\theta$ angles of 25 reflections measured on a Nonius CAD-4 automatic diffractometer with Mo $\mathrm{K} \alpha$ radiation $(\lambda=0.71073 \AA)$. 


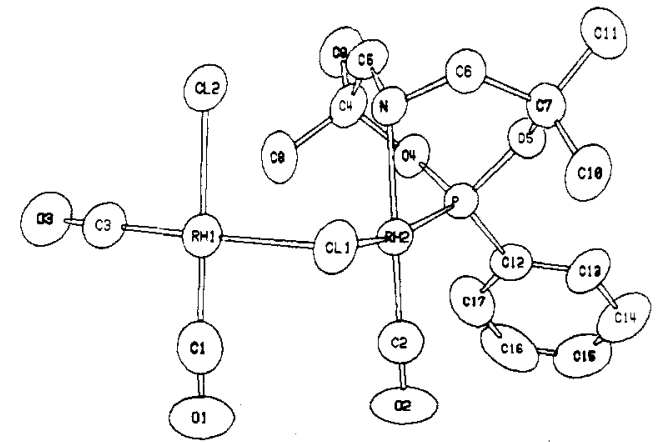

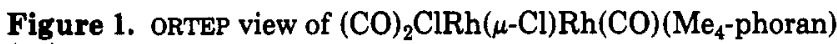
(5a).

The intensities of 3477 reflections were collected at room temperature in the range $2^{\circ}<\theta<23^{\circ}$. Absorption corrections were negligible, owing to the size of the monocrystal $(0.27 \times 0.25$ $\times 0.13 \mathrm{~mm}$ ) and to the value of the linear absorption coefficient $\left(\mu=16.9 \mathrm{~cm}^{-1}\right)$. The characteristics of the diffractometer measurements were as follows: graphite monochromator; $\omega-2 \theta$ scan mode; scan angle, $S=1.00+0.35 \tan \theta$ (deg); detector aperture, $D=2.50+0.45 \tan \theta(\mathrm{mm})$. Equivalent reflections were averaged, and corrections for Lorentz and polarization effects were applied. Only 2805 independent reflections with $I>3 \sigma(I)$ were used for the structure determination. The program package for the calculations was Enraf-Nonius SDP; ${ }^{7}$ they were carried out on a PDP $11 / 60$ computer.

Atomic positions were obtained with program MULTAN and subsequent Fourier difference synthesis for the 28 independent non-hydrogen atoms of the molecule constituting the asymmetric unit.

Least-squares refinement of coordinates and thermal parameters, first isotropic, and then anisotropic, of these 28 atoms led to values of $R=\sum\left(\left|F_{\mathrm{o}}\right|-\mid F_{\mathrm{c}}\right) / \sum\left|F_{\mathrm{o}}\right|$ of 0.043 and $R_{\mathrm{w}}=\left[\sum w\left(\left|F_{\mathrm{o}}\right|\right.\right.$ $\left.-\left|F_{\mathrm{c}}\right|^{2} / \sum w\left|F_{\mathrm{o}}\right|^{2}\right]^{1 / 2}$ of 0.059 . At this stage the 22 independent hydrogen atoms were introduced into calculated positions, with isotropic thermal parameters equal to $5 \AA^{2}$ Most of them were found on a Fourier difference synthesis, with peak heights in the range $0.6-0.3 \mathrm{e} \AA^{-3}$. Their contribution is significant in lowering $R$ and $R_{w}$ values. Two cycles of refinement of coordinates and anisotropic thermal parameters of the 28 non-hydrogen atoms and two last cycles of refinement of the same parameters plus coordinates of hydrogen atoms and a secondary extinction coefficient led to final values of $R$ and $R_{\mathrm{w}}$ of 0.032 and 0.045 , respectively.

The final atomic coordinates and thermal parameters are given in Table I, with estimated standard deviations in parentheses. Figure 1 shows an ORTEP view of the molecule; selected interatomic distances and angles are given in Table II.

\section{Results and Discussion}

Preparative Results. When the bicyclic aminophosphorane 1a is allowed to react with $\left[\mathrm{Rh}(\mathrm{CO})_{2} \mathrm{Cl}\right]_{2}, 2$, at a $\mathrm{Rh} /$ ligand ratio of $1: 1$ in toluene at room temperature, the immediate evolution of $\mathrm{CO}$ is observed and the expected yellow adduct $3 \mathbf{a}$, which is readily soluble in toluene, is formed according to eq 1. The analytical and spectroscopic data are in good agreement with a mononuclear complex in which the nitrogen site and the carbonyl ligand are in a position trans (antisymbiotic) to each other. This has been confirmed by several X-ray structure determinations of complexes derived from similar phosphoranes by the same reaction. ${ }^{2,3}$

We have now found that when the reaction of $1 \mathrm{a}$ with 2 is carried out with a $\mathrm{Rh} /$ ligand ratio of $2: 1$ and in the absence of light, the binuclear singly bridged complex 5a

(7) Frenz, B. A. "The Enraf-Nonius CAD-4 SDP", a real time system for concurrent $X$-ray data collections and crystal structure determinations. In Schenk, H.; Olthof-Hazehamp, R.; van Koningsveld, H.; Bassi, G. C. "Computing in Crystallography", Delft University Press: Delft 1978. is formed instead. The NMR spectra show the conversion of 2 to be almost quantitative, and $\mathbf{5 a}$ was isolated in fairly good yield. In the presence of light some decomposition is observed during the reaction; in contrast, $5 \mathrm{a}$ is much less sensitive to light in the solid state and can be stored indefinitely at $-25^{\circ} \mathrm{C}$.

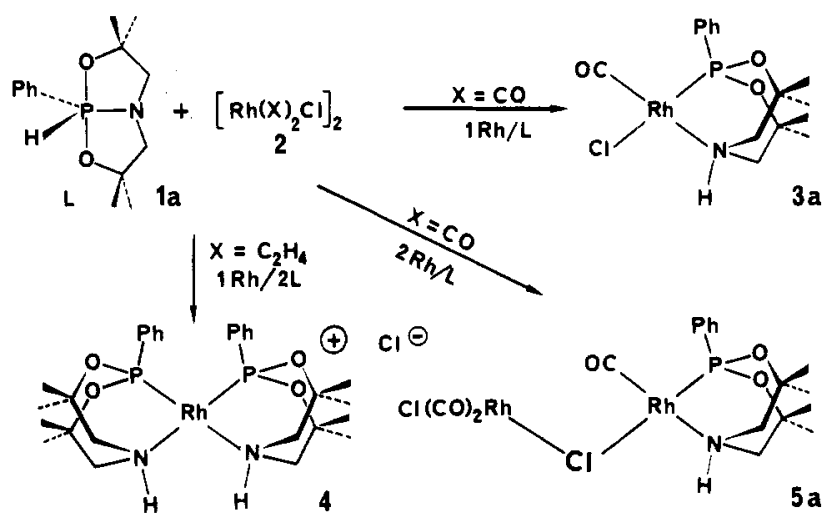

The analytical and mass spectroscopic data confirm that 5a must be formulated as a binuclear complex. Characteristic infrared data are a $\nu_{\mathrm{NH}}$ absorption at $3164 \mathrm{~cm}^{-1}$, typical of a metal coordinated nitrogen atom, and three terminal $\nu_{\mathrm{CO}}$ absorptions at 2074,2008 , and $1998 \mathrm{~cm}^{-1}$. Only one doublet, with $J_{\mathrm{P}-\mathrm{Rh}}=180 \mathrm{~Hz}$, is found in the ${ }^{31} \mathrm{P}$ NMR spectrum in $\mathrm{Me}_{2} \mathrm{SO}$, and only one set of methyl and methylene signals appears in the ${ }^{1} \mathrm{H}$ spectrum in $\mathrm{C}_{6} \mathrm{D}_{6}$ : there is no evidence of the presence of other species in the solutions of $\mathbf{5 a}$, and the product recovered by evaporation of the latter solution is identical with the initial sample. Both ${ }^{1} \mathrm{H}$ and ${ }^{31} \mathrm{P}$ NMR spectra are close to, but definitely distinct from, those of the mononuclear complex 3a. As the spectroscopic data alone could however not unequivocally elucidate the nature of the bridging ligand (chlorine or aminophosphane), an X-ray structural investigation has been carried out on complex 5a (vide infra).

Similar behavior was observed when $\left[\mathrm{Rh}(\mathrm{CO})_{2} \mathrm{Cl}\right]_{2}$ was allowed to react with the unsubstituted bicyclic aminophosphorane $\mathrm{H}\left(\mathrm{C}_{6} \mathrm{H}_{5}\right) \widehat{\mathrm{P}\left(\mathrm{OCH}_{2} \mathrm{CH}_{2}\right)_{2} \mathrm{~N}}, 1 b^{2}$ (abbreviated phoran), under the same conditions as described for $\mathbf{5 a}$. The IR spectroscopic monitoring of the reaction and the examination of the crude reaction mixture isolated give strong evidence for the formation of approximately equal proportions of both the previously reported mononuclear complex (CO)ClRh(phoran) $3 \mathbf{b}^{2}$-absent in the case of $\mathrm{Me}_{4}$-phoran-and of the new binuclear singly bridged complex (CO) ${ }_{2} \mathrm{ClRh}(\mu-\mathrm{Cl}) \mathrm{Rh}(\mathrm{CO})$ (phoran) (5b) (CO absorptions at 2090, 2030, 2005, and $1985 \mathrm{~cm}^{-1}$ in $\mathrm{KBr}$ ). Unfortunately the separation of the two complexes could not be achieved because of their similar solubilities and their strong adsorption on $\mathrm{SiO}_{2}$ during the attempted chromatographic separation.

The single $\mathrm{Rh}-\mathrm{Cl}-\mathrm{Rh}$ bridge in 5 was expected to be prone to cleavage reactions under the action of nucleophiles. As a typical example, with 1 equiv of $\mathrm{Me}_{4}$-phoran $\mathbf{5 a}$ gives the mononuclear complex $3 \mathbf{a}$, which was isolated in $40 \%$ yield. Complex $3 a$ was completely characterized by means of analytical and spectroscopic data and by its identification with an independently prepared sample produced by the reaction of $\left[\mathrm{Rh}(\mathrm{CO})_{2} \mathrm{Cl}\right]_{2}$ with $\mathrm{Me}_{4}$-phoran in a $1: 1 \mathrm{Rh} /$ ligand ratio.

Molecular Structure of $(\mathrm{CO})_{2} \mathrm{ClRh}(\mu-\mathrm{Cl}) \mathrm{Rh}(\mathrm{CO})$ ( $\mathbf{M e}_{4}$-phoran), 5a. The molecular structure of $\mathbf{5 a}$ is shown in Figure 1. Its most remarkable and unprecedented feature is the presence of a single chlorine bridge between the two rhodium atoms. The $\mathrm{Rh}(2)-\mathrm{Cl}(2)$ distance of 4.153 


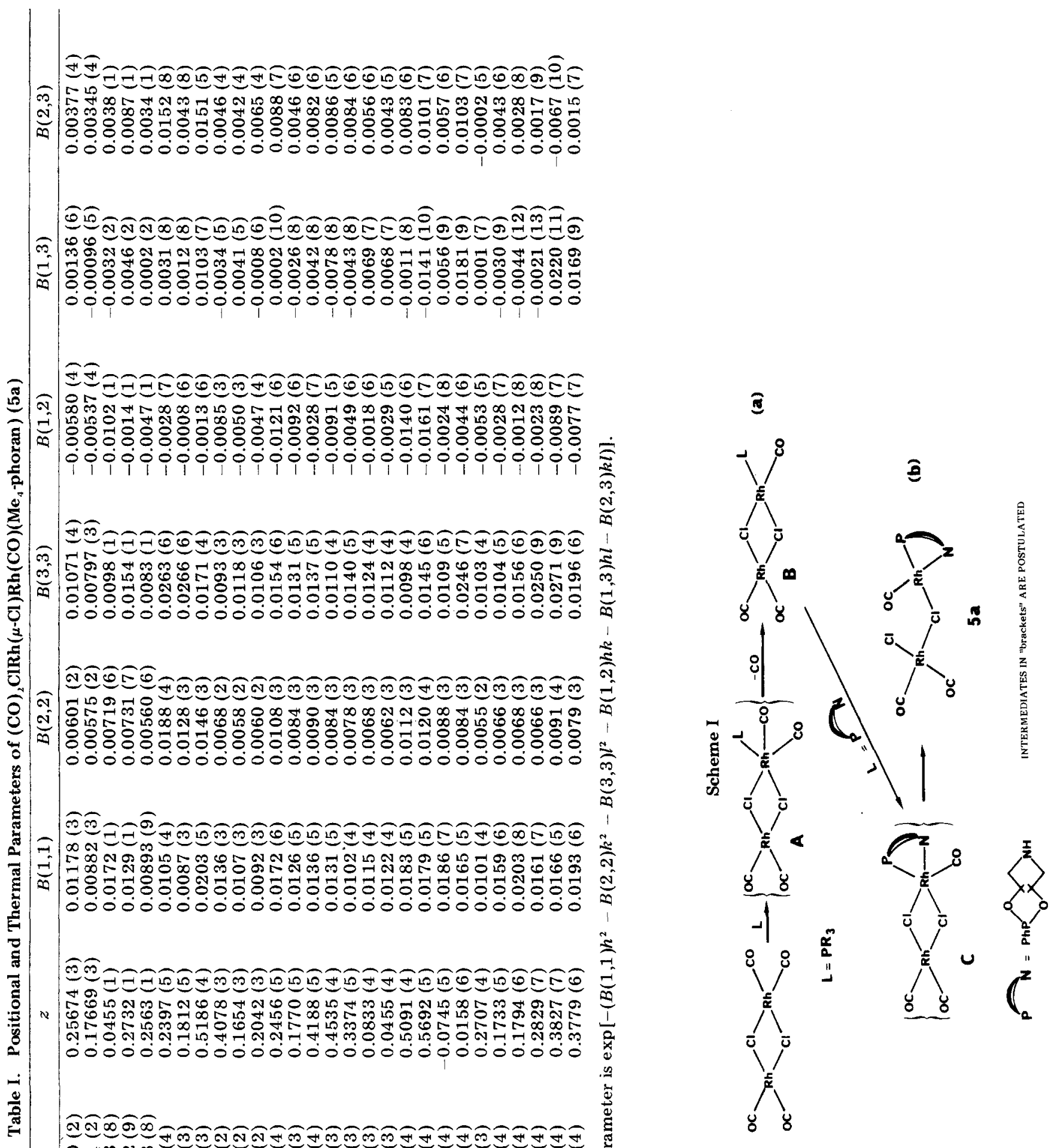


Table II. Selected Bond Lengths $(d, \AA)$ and Bond Angles $(\omega, \mathrm{deg})$ of Complex $5 \mathrm{a}$

$\begin{array}{ll}\mathrm{Rh}(1)-\mathrm{Cl}(1) & 2.372(1) \\ \mathrm{Rh}(1)-\mathrm{Cl}(2) & 2.352(1) \\ \mathrm{Rh}(1)-\mathrm{C}(1) & 1.838(5) \\ \mathrm{Rh}(1)-\mathrm{C}(3) & 1.829(4) \\ \mathrm{Rh}(2)-\mathrm{Cl}(1) & 2.454(1) \\ \mathrm{Rh}(2)-\mathrm{P} & 2.156(1) \\ \mathrm{Rh}(2)-\mathrm{N} & 2.164(3) \\ \mathrm{Rh}(2)-\mathrm{C}(2) & 1.842(4) \\ \operatorname{Rh}(1) \cdots \operatorname{Rh}(2) & 3.393(1)\end{array}$

$\mathrm{Cl}(1)-\mathrm{Rh}(1)-\mathrm{Cl}(2)$

$\mathrm{Cl}(1)-\mathrm{Rh}(1)-\mathrm{C}(1)$

$\mathrm{Cl}(1)-\mathrm{Rh}(1)-\mathrm{C}(3)$

$\mathrm{Cl}(2)-\mathrm{Rh}(1)-\mathrm{C}(1)$

$\mathrm{Cl}(2)-\mathrm{Rh}(1)-\mathrm{C}(3)$

$\mathrm{C}(1)-\mathrm{Rh}(1)-\mathrm{C}(3)$

$\mathrm{Cl}(1)-\mathrm{Rh}(2)-\mathrm{P}$

$\mathrm{Cl}(1)-\mathrm{Rh}(2)-\mathrm{N}$

$\mathrm{Cl}(1)-\mathrm{Rh}(2)-\mathrm{C}(2)$

P-Rh(2)-N

$\mathrm{P}-\mathrm{Rh}(2)-\mathrm{C}(2)$

$\mathrm{N}-\mathrm{Rh}(2)-\mathrm{C}(2)$

$\mathrm{Rh}(1)-\mathrm{Cl}(1)-\mathrm{Rh}(2)$

$\mathrm{Rh}(1)-\mathrm{C}(1)-\mathrm{O}(1)$
Bond Lengths $(d)$

$\begin{array}{llll}\mathrm{P} \cdots \mathrm{N} & 2.705(2) & \mathrm{C} 3-\mathrm{O} 3 & 1.133(5) \\ \mathrm{Cl}(2) \cdots \mathrm{N} & 3.269(\cdots) & \mathrm{O} 4-\mathrm{C} 4 & 1.491(4) \\ \mathrm{P}-\mathrm{O}(4) & 1.583(2) & \mathrm{O} 5-\mathrm{C} 7 & 1.482(4) \\ \mathrm{P}-\mathrm{O}(5) & 1.598(2) & \mathrm{C} 4-\mathrm{C} 5 & 1.504(6) \\ \mathrm{P}-\mathrm{C}(12) & 1.805(3) & \mathrm{C} 4-\mathrm{C} 8 & 1.527(6) \\ \mathrm{N}-\mathrm{C} 5 & 1.501(5) & \mathrm{C} 4-\mathrm{C} 9 & 1.511(5) \\ \mathrm{N}-\mathrm{C} 6 & 1.481(5) & \mathrm{C} 6-\mathrm{C} 7 & 1.561(5) \\ \mathrm{C} 1-\mathrm{O} 1 & 1.150(6) & \mathrm{C} 7-\mathrm{C} 10 & 1.500(6) \\ \mathrm{C} 2-\mathrm{O} 2 & 1.132(5) & \mathrm{C} 7-\mathrm{C} 11 & 1.510(6)\end{array}$

Bond Angles $(\omega)$

$\begin{array}{rllll}90.89(4) & \mathrm{Rh}(1)-\mathrm{C}(3)-\mathrm{O}(3) & 177.9(4) & \mathrm{C}(5)-\mathrm{C}(4)-\mathrm{C}(8) & 114.9(3) \\ 89.4(2) & \mathrm{Rh}(2)-\mathrm{C}(2)-\mathrm{O}(2) & 179.5(4) & \mathrm{C}(5)-\mathrm{C}(4)-\mathrm{C}(9) & 109.4(4) \\ 178.6(1) & \mathrm{Rh}(2)-\mathrm{P}-\mathrm{O}(4) & 113.14(9) & \mathrm{C}(8)-\mathrm{C}(4)-\mathrm{C}(9) & 110.5(4) \\ 179.4(2) & \mathrm{Rh}(2)-\mathrm{P}-\mathrm{O}(5) & 108.97(9) & \mathrm{N}-\mathrm{C}(5)-\mathrm{C}(4) & 117.7(3) \\ 87.8(1) & \mathrm{Rh}(2)-\mathrm{P}-\mathrm{C}(12) & 124.7(1) & \mathrm{N}-\mathrm{C}(6)-\mathrm{C}(7) & 115.0(3) \\ 91.9(2) & \mathrm{O}(4)-\mathrm{P}-\mathrm{O}(5) & 103.7(1) & \mathrm{O}(5)-\mathrm{C}(7)-\mathrm{C}(6) & 111.0(3) \\ 162.20(3) & \mathrm{O}(4)-\mathrm{P}-\mathrm{C}(12) & 101.2(1) & \mathrm{O}(5)-\mathrm{C}(7)-\mathrm{C}(10) & 108.8(3) \\ 89.06(8) & \mathrm{O}(5)-\mathrm{P}-\mathrm{C}(12) & 102.9(1) & \mathrm{O}(5)-\mathrm{C}(7)-\mathrm{C}(11) & 104.7(3) \\ 99.9(1) & \mathrm{Rh}(2)-\mathrm{N}-\mathrm{C}(5) & 121.7(2) & \mathrm{C}(6)-\mathrm{C}(7)-\mathrm{C}(10) & 112.1(4) \\ 77.37(8) & \mathrm{Rh}(2)-\mathrm{N}-\mathrm{C}(6) & 109.4(2) & \mathrm{C}(6)-\mathrm{C}(7)-\mathrm{C}(11) & 108.8(3) \\ 94.4(1) & \mathrm{C}(5)-\mathrm{N}-\mathrm{C}(6) & 111.4(3) & \mathrm{C}(10)-\mathrm{C}(7)-\mathrm{C}(11) & 111.3(4) \\ 170.6(1) & \mathrm{O}(4)-\mathrm{C}(4)-\mathrm{C}(5) & 110.4(3) & \mathrm{P}-\mathrm{O}(4)-\mathrm{C}(4) & 120.3(2) \\ 89.36(3) & \mathrm{O}(4)-\mathrm{C}(4)-\mathrm{C}(8) & 106.8(3) & \mathrm{P}-\mathrm{O}(5)-\mathrm{C}(7) & 126.0(2) \\ 176.3(4) & \mathrm{O}(4)-\mathrm{C}(4)-\mathrm{C}(9) & 104.5(3) & & \end{array}$

Table III. Weighted Least-Squares Planes

\begin{tabular}{|c|c|c|c|c|c|c|c|c|c|c|}
\hline \multirow[b]{2}{*}{ atoms defining the planes } & \multirow[b]{2}{*}{ plane } & \multicolumn{9}{|c|}{ distances of atoms $(\AA)$ to the best plane } \\
\hline & & $\mathrm{Rh}(1)$ & $\operatorname{Rh}(2)$ & $\mathrm{Cl}(1)$ & $\mathrm{Cl}(2)$ & $\mathrm{C}(1)$ & $C(2)$ & $\mathrm{C}(3)$ & $\mathbf{P}$ & $\mathbf{N}$ \\
\hline $\begin{array}{l}\mathrm{Rh}(1), \mathrm{Cl}(1), \mathrm{Cl}(2), \mathrm{C}(1), \mathrm{C}(3) \\
\mathrm{Rh}(2), \mathrm{Cl}(1), \mathrm{P}, \mathrm{N}, \mathrm{C}(2) \\
\mathrm{Cl}(1), \mathrm{P}, \mathrm{N}, \mathrm{C}(2)\end{array}$ & $\begin{array}{l}1 \\
2 \\
3\end{array}$ & $\begin{array}{r}0.000 \\
-2.194\end{array}$ & $\begin{array}{l}-2.453 \\
-0.022 \\
-0.214\end{array}$ & $\begin{array}{l}0.001 \\
0.167 \\
0.018\end{array}$ & -0.001 & -0.018 & $\begin{array}{r}0.154 \\
-0.355\end{array}$ & 0.019 & $\begin{array}{l}0.155 \\
0.019\end{array}$ & $\begin{array}{l}-0.367 \\
-0.187\end{array}$ \\
\hline
\end{tabular}

(1) $\AA$ excludes any bridging character for $\mathrm{Cl}(2)$. Otherwise $5 \mathrm{a}$ is best described by two square-planar arrangements of ligands, each centered around one of the metal atoms, these two moieties being linked together by the single bridging chlorine atom $\mathrm{Cl}(1)$ in such a way that the $\mathrm{CO}$ groups $C(1)$ and $C(2)$ are cis oriented to each other. The two planes together form a dihedral angle of $86.2^{\circ}$. Generally the $\mathrm{Cl}-\mathrm{Rh}-\mathrm{Cl}$ angle in bis ( $\mu$-chloro)-bridged $\mathrm{Rh}(\mathrm{I})$ complexes is ca. $85^{\circ},{ }^{9}$ whereas in $5 \mathrm{a}$ the angles between the four ligands $\mathrm{Cl}(1), \mathrm{Cl}(2), \mathrm{C}(1)$, and $\mathrm{C}(3)$ around $\mathrm{Rh}(1)$ are all close to $90^{\circ}$. Thus the square-planar configuration around this atom is closer to ideal than in the precursor 2. ${ }^{8}$ In the case of the second rhodium atom $\mathrm{Rh}(2)$, the four ligands $\mathrm{Cl}(1), \mathrm{C}(2), \mathrm{P}$, and $\mathrm{N}$ do not lie as strictly in the mean plane (Table III). This moiety is comparable to the well-documented structures of the $\mathrm{LRh}(\mathrm{CO}) \mathrm{Cl}$ chelates, where $\mathrm{L}$ is either the unsubstituted or the dimethyl-substituted analogue of the $\mathrm{Me}_{4}$-phoran ligand $1 \mathrm{a}^{3}{ }^{3}$ The only difference is the significantly sharper $\mathrm{Cl}(1)-$ $\mathrm{Rh}(2)-\mathrm{P}$ angle $\left(162.2^{\circ}\right.$ vs. $168.5^{\circ}$ and $\left.170.0^{\circ}\right)$, which may be a consequence of the geometrical constraints caused by the introduction of two gem-dimethyl groups in 1a.

The original characteristics of compound 5a, besides its having a single bridging chloro atom, $\mathrm{Cl}(1)$, lie in the different actual charges borne by the two metal atoms and in their asymmetrical substitution. The inequivalent $\mathrm{Rh}(1)-\mathrm{Cl}(1)$ and $\mathrm{Rh}(2)-\mathrm{Cl}(1)$ bond lengths $(2.372$ (1) vs. 2.454 (1) $\AA$ ) may be explained either by the difference in actual charges - the bridging chlorine atom being expected not to behave as a one-sided donor but to share its electrons in a similar fashion between the two metal atomsand consequent differences in radii or by the distinct trans influences exerted by the phosphane and carbonyl ligands.

(8) Dahl, L. F.; Martell, C.; Wampler, D. J. J. Am. Chem. Soc. 1961, 83,176 .
In view of the stronger $\pi$-acceptor character of the latter, its trans influence should indeed lead to a shorter Rh(1)-Cl(1) than $\mathrm{Cl}(1)-\mathrm{Rh}(2)$ distance. Although there is no definite way to apportion the observed difference in metal-chlorine distances between these two factors, it seems however from the literature that the trans influence should be rather slight..$^{3,9}$ The $\mathrm{Rh}(1)-\mathrm{Cl}(1)-\mathrm{Rh}(2)$ angle of $89.36(3)^{\circ}$ could allow the Rh atoms to interact weakly, as suggested by Dahl in the case of $\left[\mathrm{Rh}(\mathrm{CO})_{2} \mathrm{Cl}\right]_{2},{ }^{8}$ the actual distance between the metal atoms being 3.393 (1) $\AA\left(3.2 \AA\right.$ in $\left.\left[\mathrm{Rh}(\mathrm{CO})_{2} \mathrm{Cl}\right]_{2}\right)$.

Whereas the hitherto known $\mathrm{L}_{2} \mathrm{Rh}(\mu-\mathrm{Cl})_{2} \mathrm{RhL}_{2}$ complexes are characterized by two square planes linked together by two chloro bridges, thus forming rigid dihedrals with angles between 115.8 and $180^{\circ},{ }^{9}$ which block the molecules in a single conformation, several conformational isomers might be expected for compound 5a due to rotation around the $\mathrm{Rh}-\mathrm{Cl}$ single bridge. The cis orientation found for the carbonyl groups $\mathrm{C}(1)$ and $\mathrm{C}(2)$ in the solid state may be due to a $\mathrm{Cl}(2) \cdots \mathrm{H}-\mathrm{N}$ hydrogen bond. The intramolecular distance found for $\mathrm{N}-\mathrm{Cl}(2)(3.269 \AA)$ lies at the upper limit of the range of values usually accepted (3.16-3.26 $\AA$ ) for such hydrogen bonds. ${ }^{10}$ Concomitantly, a slight depression of the $\nu_{\mathrm{NH}}$ vibration $\left(36 \mathrm{~cm}^{-1}\right)$ is found for $\mathbf{5 a}$ in the IR spectrum when compared to the mononuclear complex 3a.

Reaction Pathways. It is well established that the reaction of phosphanes with $\left[\mathrm{Rh}(\mathrm{CO})_{2} \mathrm{Cl}_{2}\right.$ proceeds via bis( $\mu$-chloro)dirhodium complexes, the composition of which depends on their stoichiometry. ${ }^{4}$ The complete series of substitution products of formula $\mathrm{Rh}_{2} \mathrm{Cl}_{2}(\mathrm{CO})_{4-m^{-}}$ $\left(\mathrm{PR}_{3}\right)_{m}(m=0-4)$ has been identified in solution ${ }^{11}$ with the

(9) Bonnet, J. J.; Jeannin, Y.; Kalck, P.; Maisonnat, A.; Poilblanc, R. Inorg. Chem. 1975, 14, 743 and references cited therein.

(10) "International Tables for X-Ray Crystallography"; Kynoch Press: Birmingham, 1968; Vol. III, p 273. 
exception of the dissymetrically substituted $\mathrm{Rh}_{2} \mathrm{Cl}_{2}$ $(\mathrm{CO})_{2}\left(\mathrm{PR}_{3}\right)_{2}$ isomer, and $\left[\mathrm{Rh}(\mu-\mathrm{Cl})(\mathrm{CO})\left(\left(\mathrm{CH}_{3}\right)_{2} \mathrm{PC}_{6} \mathrm{H}_{5}\right\}\right]_{2}$ was even stable enough to allow an X-ray structural determination to be made. ${ }^{9}$ A larger excess of ligand then results in bridge cleavage and formation of mononuclear (CO)ClRh $\left(\mathrm{PR}_{3}\right)_{2}$ complexes. Chelating ligands either follow the same reaction pathway ${ }^{2,12}$ or displace the chloride bridges by ligand bridges, ${ }^{13}$ thus preserving the dinuclear doubly bridged character of the adducts. No example of a singly bridged dinuclear rhodium(I) complex appears to have been reported so far, but the influence of the stoichiometry of these ligands on the issue of the reaction has not been investigated.

The formation of $5 \mathrm{a}$ from a $\mathrm{Rh} /$ ligand ratio of $2: 1$ extends the range of hitherto assumed reaction pathways, as shown in Scheme I. It leads to the proposal that an incoming phosphonite ligand such as $\mathrm{Me}_{4}$-phoran should first form a monodentate, phosphorus only bound complex corresponding to structure $\mathrm{B}$ via a pentacoordinated intermediate $\mathrm{A}$, according to the presently accepted scheme. However, it must be noted that, although several examples of moriocoordination of the cyclic aminophosphanes at transition-metal centers through the phosphorus site only have been established, ${ }^{14}$ no $\mathrm{Rh}$ complex in which these

(11) Gallay, J.; De Montanzon, D.; Poilblanc, R. J. Organomet. Chem. $1972,38,179$.

(12) Rauchfuss, T. B.; Roundhill, D. M. J. Am. Chem. Soc. 1974, 96, 3098.

(13) Haines, R. J.; Meintjies, E.; Laing, M. Inorg. Chim. Acta 1979, 36, L403; Farr, J. P.; Olmstead, M. M.; Hunt, C. H.; Balch, A. L. Inorg. Chem. 1981, 20, 1182. Crocker, C.; Errington, R. J.; Markham, R.; Moulton, C. J.; Shaw, B. L. J. Chem. Soc., Dalton Trans. 1982, 387.

(14) Wachter, J.; Jeanneaux, F.; Riess, J. G. Inorg. Chem. 1980, 19 , 2169. Wachter, J.; Mitschler, A.; Riess, J. G. J. Am. Chem. Soc. 1981, 103, 2121. phosphanes behave as monodentate ligands has as yet been identified. The addition of the free nitrogen site could then take place at the same $R h$ atom to give intermediate $C$ and then $5 \mathbf{a}$ (Scheme Ib). The formation of $5 \mathbf{a}$ may be favored by the constraint caused by the presence of two gem-dimethyl groups. It is noteworthy that no $\mathrm{P}-\mathrm{N}$ bridged complex could be observed. An extension of this pathway to other phosphorus/nitrogen bidentate ligands should be possible, as exemplified by a comparative experiment with the unsubstituted parent compound $\mathrm{H}\left(\mathrm{C}_{6} \mathrm{H}_{5}\right) \stackrel{\mathrm{P}\left(\mathrm{OCH}_{2} \mathrm{C} \text { - }\right.}{\text { - }}$ $\overrightarrow{\left.\mathrm{H}_{2}\right)_{2} \mathrm{~N}}$, which, in addition to the mononuclear complex (CO)ClRh(phoran), gives the binuclear complex $\mathbf{5 b}$ analogous to $\mathbf{5 a}$.

The novel character of this dirhodium species, with a single chlorine bridge, should open new prospects in reactivity and structures. Under the action of nucleophiles and small unsaturated molecules, for example, these reactions may proceed either via a halide bridge cleavage or via a stabilization of the dinuclear arrangement by means of the formation of new, additional, bridges. Preliminary results on the addition of $\mathrm{CO}, \mathrm{SO}_{2}$, and alkynes show indeed that both pathways may be operative; this will be the subject of further investigations.

Acknowledgment. J.W. is grateful to Prof. H. Brunner and F.J., G.L.B., and J.G.R. are grateful to CNRS for generous support of this work.

Registry No. 1a, 90132-09-5; 3a, 70415-00-8; 5a, 90108-65-9; $\left[\mathrm{Rh}(\mathrm{CO})_{2} \mathrm{Cl}\right]_{2}, 14523-22-9$.

Supplementary Material Available: Tables of positional and thermal parameters of hydrogen atoms, general temperature factor expressions, and structure factors (14 pages). Ordering information is given on any current masthead page.

\title{
Molecular and Electronic Structure of $(\mathrm{CO})_{2} \mathrm{Co}(\mu-\mathrm{CO})\left[\mu-\mathrm{C}(\mathrm{SMe})_{2}\right] \mathrm{Fe}\left(\eta^{5}-\mathrm{C}_{5} \mathrm{H}_{5}\right)(\mathrm{CO})$
}

\author{
John R. Matachek, ${ }^{1 a}$ Robert J. Angelici, ${ }^{1 a}$ Kimberly A. Schugart, ${ }^{16}$ Kenneth J. Haller, ${ }^{16}$ and \\ Richard F. Fenske* $1 \mathrm{~b}$ \\ Department of Chemistry and Ames Laboratory-U.S. DOE, Iowa State University, Ames, Iowa 50011, and \\ Department of Chemistry, University of Wisconsin-Madison, Madison, Wisconsin 53706
}

Received March 20, 1984

The reaction of $\mathrm{Co}(\mathrm{CO})_{4}{ }^{-}$with the dithiocarbene complex $\mathrm{Cp}(\mathrm{CO})(\mathrm{MeCN}) \mathrm{Fe}=\mathrm{C}(\mathrm{SMe})_{2}{ }^{+}$yields the dinuclear $(\mathrm{CO})_{2} \mathrm{Co}(\mu-\mathrm{CO})\left[\mu-\mathrm{C}(\mathrm{SMe})_{2}\right] \mathrm{Fe}(\mathrm{Cp})(\mathrm{CO})$, which was originally formulated on the basis of spectroscopic results as a compound with the carbon of the $\mathrm{C}(\mathrm{SMe})_{2}$ carbene ligand bridging the $\mathrm{Co}-\mathrm{Fe}$ bond. An X-ray diffraction study now indicates a sulfur atom of the carbene is also bonded to the Co. The compound crystallizes in orthorhombic space group $\mathrm{Pbca}$ with eight formula units per unit cell. Cell dimensions are $a=14.252(4), b=20.235(4)$, and $c=10.353(2) \AA$. The structure has been refined to $R=0.029$. The Co-Fe bond, 2.502 (1) $\AA$, is bridged by a CO group and a carbene ligand, Co-C(carbene), $1.916(2) \AA$, and $\mathrm{Fe}-\mathrm{C}$ (carbene), $1.966(2) \AA$. One sulfur atom of the bridging $\mathrm{C}(\mathrm{SMe})_{2}$ unit coordinates to the Co giving a triangular $\mathrm{Co}-\mathrm{C}-\mathrm{S}$ grouping and a highly distorted bridging carbene carbon atom. A molecular orbital calculation provides insight into the bonding interactions that stabilize this unusual bridging carbene ligand.

\section{Introduction}

Recent interest in the synthesis and reactivity of bimetallic bridged carbene complexes evolves from the proposed or demonstrated involvement of these and similar species in carbon monoxide reduction chemistry ${ }^{2}$ and olefin

(1) (a) Department of Chemistry and Ames Laboratory-U.S. DOE, Iowa State University, Ames, IA. (b) Department of Chemistry, University of Wisconsin-Madison, Madison, WI. metathesis ${ }^{3}$ along with a variety of other reactions. ${ }^{4}$ While a plethora of carbene-bridged complexes exists, only a few

(2) (a) Masters, C. Adv. Organomet. Chem. 1979, 17, 61. (b) Muetterties, E. L.; Stein, J. Chem. Rev. 1979, 79, 479. (c) Dyke, A. F.; Guerchais, J. E.; Knox, S. A. R.; Roue, J.; Short, R. L.; Taylor, G. E.; Woodward, P. J. Chem. Soc., Chem. Commun. 1981, 537. (d) Brady, R. C., III; Pettit, R. J. Am. Chem. Soc. 1980, 102, 6181. (e) Steinmetz, G. R.; Geoffroy, G. L. Ibid. 1981, 103, 1278. (f) Cooke, M.; Davies, D. L.; Guerchais, J. E.; Knox, S. A. R. J. Chem. Soc., Chem. Commun. 1981, 862. (g) Herrmann, W. A. Angew. Chem., Int. Ed. Engl. 1982, 21, 117. 